\title{
Bacterial Resistance and Mortality in an Intensive Care Unit
}

\author{
Adriana Cristina de Oliveira ${ }^{1}$ \\ Rafael Souza Silva ${ }^{2}$ \\ Mario E. Piscoya Díaz ${ }^{3}$ \\ Robert Aldo Iquiapaza ${ }^{4}$
}

The goal was to identify risk factors for healthcare-associated infections by resistant microorganisms and patient mortality in an Intensive Care Unit. A prospective and descriptive epidemiological research was conducted from 2005 till 2008, involving 2300 patients. Descriptive statistics, bivariate and multivariate logistic regression analysis were used. In bivariate analysis, infection caused by resistant microorganism was significantly associated to patients with community-acquired infection $(p=0.03 ; O R=1.79)$ and colonization by resistant microorganism $(p<0.01 ; O R=14.22)$. In multivariate analysis, clinical severity $(p=0.03 ; O R=0.25)$ and colonization by resistant microorganism $(p<0.01$; $\mathrm{OR}=21.73$ ) were significant. Mortality was associated to the following risk factors: type of patient, average severity index, besides mechanical ventilation. The relation between resistant microorganisms and death shows the need to monitor adherence to infection control measures so as to improve care quality and mainly survival of critical patients.

Descriptors: Epidemiologic Surveillance; Cross Infection; Intensive Care Units; Mortality; Drug Resistance, Microbial.

1 RN, Post-doctoral, Adjunct Professor, Escola de Enfermagem, Universidade Federal de Minas Gerais, MG, Brazil. E-mail: adrianacoliveira@gmail.com.

2 RN. E-mail: rafeudes@yahoo.com.br.

${ }^{3}$ Statistician, Doctoral Student in Demography, Centro de Desenvolvimento e Planejamento Regional, Universidade Federal de Minas Gerais, MG, Brazil.

${ }^{4}$ Economist, Ph.D. in Finances, Professor, Universidade Federal de Minas Gerais, MG, Brazil. E-mail: riquiapaza@gmail.com.

Corresponding Author:

Adriana Cristina de Oliveira

Universidade Federal de Minas Gerais. Escola de Enfermagem.

Av. Alfredo Balena, 190 - Campus Saúde

CEP: 30130-100 Belo Horizonte, MG, Brasil

E-mail: adrianacoliveira@gmail.com 


\section{Resistência bacteriana e mortalidade em um centro de terapia intensiva}

Objetivou-se identificar fatores de risco para o desenvolvimento de infecções, relacionadas ao cuidar em saúde, por microrganismos resistentes e a mortalidade dos pacientes em um centro de terapia intensiva. Trata-se de estudo epidemiológico prospectivo, realizado entre 2005 e 2008, envolvendo 2.300 pacientes. Utilizou-se estatística descritiva, análise de regressão logística bivariada e multivariada. Na análise bivariada, a infecção por microrganismo resistente esteve significativamente associada a pacientes com infeç̧ão comunitária $(p=0,03 ; O R=1,79)$ e colonização por microrganismo resistente $(p<0,01 ; O R=14,22)$. Na análise multivariada, severidade clínica $C(p=0,03 ; O R=0,25)$ e colonização por microrganismo resistente $(p<0,01 ; O R=21,73)$ foram significativas. Para óbitos, observou-se, como fator de risco: tipo de paciente, severidade clínica e uso de ventilação mecânica. A constatação da relação entre microrganismo resistente e óbitos evidencia a necessidade de monitorização da adesão às medidas de controle de infecção, no sentido de melhorar a qualidade da assistência e, sobretudo, a sobrevida de pacientes críticos.

Descritores: Vigilância Epidemiológica; Infecção Hospitalar; Unidades de Terapia Intensiva; Mortalidade; Resistência Microbiana a Medicamentos.

\section{Resistencia bacteriana y mortalidad en un Centro de Terapia Intensiva}

Se objetivó identificar factores de riesgo para el desarrollo de infecciones relacionadas al cuidar en salud, por microorganismos resistentes, y también investigar su relación con la mortalidad de los pacientes en un centro de terapia intensiva. Se trata de un estudio epidemiológico prospectivo realizado entre 2005 y 2008, envolviendo 2.300 pacientes. Se utilizó la estadística descriptiva y el análisis de regresión logístico bivariado y multivariado. En el análisis bivariado, la infección por microorganismos resistentes estuvo significativamente asociada a pacientes con infección comunitaria $(p=0,03$; $\mathrm{OR}=1,79)$ y a la colonización por microorganismo resistente $(p<0,01 ; O R=14,22)$. En el análisis multivariado la severidad clínica $C(p=0,03 ; O R=0,25)$ y la colonización por microorganismo resistente $(p<0,01 ; O R=21,73)$ fueron significativas. En relación a las muertes, se observó como factor de riesgo: el tipo de paciente, la severidad clínica, y el uso de ventilación mecánica. La constatación de la relación entre los microorganismos resistentes y la muerte, coloca en evidencia la necesidad de monitorizar la adhesión a las medidas de control de la infección con el objetivo de mejorar la calidad de la asistencia $y$, sobre todo, la sobrevivencia de los pacientes críticos.

Descriptores: Vigilancia Epidemiológica; Infección Hospitalaria; Unidades de Terapia Intensiva; Mortalidad; Farmacorresistencia Microbiana.

\section{Introduction}

Intensive Care Units (ICUs) deliver care to patients in clinically severe conditions, generally involving extended hospitalization and invasive procedures (central venous catheters, indwelling urinary catheters and mechanical ventilation). Hence, patients admitted to ICUs are more susceptible to the development of healthcare-associated infections (HAI), representing about $25 \%$ of all hospital infections, and especially by resistant microorganisms ${ }^{(1)}$. 
In the global context, the growing emergence of microorganisms resistant to antimicrobials has been a great source of concern, due to the prolonged hospitalization time, higher treatment cost, the reduced therapeutic arsenal and/or the risk of patient death(2).

In addition, it is important to highlight that patients undergoing critical care are more predisposed to a range of hospital infections, especially caused by multi-resistant microorganisms, due to the complex nature of care in intensive care units, multiple interventions and factors related to patients themselves.

Data from North American studies indicate that up to $50 \%$ of ICU infections are associated with the use of invasive procedures, caused by resistant microorganisms, frequently Acinetobacter $s p$, methicillin-resistant Pseudomonas sp. Klebsiella sp. Staphylococcus aureus (MRSA) and Escherichia coli(1-5). In Brazil, research at intensive care units report on an association between, on the one hand, use of indwelling urinary catheters, central catheters and mechanical ventilation and, on the other, increased infections developed at these units, a situation in which more than $75 \%$ of patients with infections use these procedures. Also, the predominance of resistant agents like Staphylococcus aureus, Pseudomonas aeruginosa and Klebisiella Pneumoniae is observed(6-9).

In addition, mortality rates at ICUs is high, ranging from nine to $38 \%$. When patients developed infections caused by resistant microorganisms, this rate can rise up to $70 \%{ }^{(3,10-11)}$. Brazilian studies reports similar rates, reaching $50 \%$ when associated with infections by resistant microorganisms ${ }^{(8-9)}$.

Given the relevance of the theme and the complexity of intensive care patients, this study aimed to identify the factors associated with the risk of developing healthcareassociated infections caused by resistant microorganisms and patient mortality at an ICU of a university hospital.

\section{Methods}

A prospective and descriptive epidemiological study was carried out at the adult Intensive Care Unit of a university hospital.

All patients admitted to the ICU, and hospitalized for more than 24 hours between August 2005 and July 2008 were eligible for the study, excluding those patients with incomplete or missing data in the patient chart records related to the research variables.

\section{Unit characteristics}

The Intensive Care Unit consists of four general rooms with four beds each, and two other beds with adequate structure for patient isolation (with private washbasins and bathroom), subject to indication by physicians or the Hospital Infection Control Commission (HICC), thus totaling eighteen active beds.

This unit comprises a highly trained multiprofessional team that delivers patient care, approximately $90 \%$ originating in the unified health system (SUS) and the remainder in health insurances and private patients.

\section{Definitions}

The following definitions were adopted, according to the National Nosocomial Infections Surveillance (NNIS) System:

- Community-acquired infections: infections notified upon the patient's admission to the unit, originating in the community, another hospital or other hospitalization units in the study hospital.

- Surgical patients: patients submitted to surgical procedures involving incision and suture, including videolaparoscopic procedures, carried out at the Surgical Center.

- Colonization by resistant microorganisms: isolation of resistant microorganisms identified in laboratory culture, without clinical or immunological signs. The determination of colonization cases was oriented by the research institution's own protocol, in which hospitalized patients coming from other hospitals with hospitalization periods of more than 72 hours or patients from the research institution hospitalized for seven days or more were monitored through surveillance culture.

- Hospital infections or healthcare-associated infections (HAI): all infections notified at the ICU $48 \mathrm{~h}$ after the patient's admission to this unit. After the patient's discharge, during 48 hours, urinary tract infection cases associated with indwelling urinary catheter were also considered until seven days after discharge from the unit.

Clinical severity: the clinical severity index measured upon the patient's admission was considered, according to the Average Severity Index Score (ASIS):

- A: Post-operative patients who do not demand intensive medical or nursing care; discharge from the unit in up to 48 hours.

- B: Physiologically stable patients, demanding nocturnal preventive observation, without the need for intensive medical or nursing care.

- C: Physiologically stable patients demanding intensive nursing care and monitoring.

- D: Physiologically unstable patients demanding intensive medical and nursing care with frequent needs for reassessment and treatment adjustment. 
- E: Physiologically unstable patients, in coma or shock, or demanding cardiopulmonary resuscitation or intensive medical and nursing care, with frequent needs for reassessment.

\section{Resistance markers}

Nowadays, various methods exist to assess the susceptibility test to available antimicrobials, which are standardized in terms of use, execution and interpretation. The Clinical and Laboratory Standards Institute (CLSI) is the referral document used by Brazilian laboratories and adopted by the Brazilian Microbial Resistance Monitoring Network, coordinated by the Health Surveillance Agency (ANVISA), in cooperation with the Pan American Health Organization (PAHO) and in partnership with the General Public Health Laboratory Coordination (CGLAB) ${ }^{(12-13)}$.

To define the bacterial resistance markers adopted in this research, the protocol established by the research institution's Hospital Infection Control Committee (HICC) was followed, in accordance with the CLSI. In other words, markers resistant to Staphylococcus aureus, to Oxacillin (analogue to methicillin in Brazil), Vancomycin (VRE) and Teicoplanin resistant Enterococcus sp. (VRE), Vancomycin resistant Streptococcus pneumoniae, Imipenem and/or Meropenem resistant Pseudomonas sp., aminoglycoside resistant enterobacteriaceae (Klebsiella, Serratia, Enterobacter, Escherichia coli, Proteus), thirdgeneration cephalosporins and fluoroquinolones.

\section{Research ethics}

A longitudinal study was carried out after approval had been obtained from the Institutional Review Board under protocol 267/2003, in compliance with Resolution $196 / 96$ by the National Health Council regarding research involving human beings.

\section{Data collection}

For data collection, nursing records and patient charts were used, besides microbiological test results. The collected data were related to gender, age, origin, clinical severity index upon admission to the ICU, patient type, time of stay at the unit, community-acquired infection diagnosis, patient colonized with resistant microorganisms during hospitalization, use of invasive procedures, hospital infection and patient outcome.

\section{Data analysis}

After completing the data collection instrument, the records were typed and processed in Statistical Package for the Social Sciences (SPSS) software, version 14 Descriptive statistical analysis was carried out to characterize the study population and logistic regression analysis was used to identify possible risk factors for the development of infections caused by resistant microorganisms, besides risk factors associated with deaths at the Intensive Care Unit. At first, bivariate models were developed to check for associations between the study variables and the observed events (infection by resistant microorganisms/death). Then, different multivariate logistic regression models were constructed to assess whether associations existed between each event and the selected characteristics, when controlled by other variables. Statistical significance was set at $\mathrm{p}<0.05$, with $95 \%$ confidence intervals.

\section{Results}

\section{Demographic profile of the population}

During the study period, 2,316 patients were assessed, 2,300 of whom (99.3\%) were eligible in function of the inclusion criteria. $52.6 \%$ were men, with a global mean age of 53 years (median 55 years), mean time of stay at the unit 5.8 days (median three days) and mainly admitted (48.5\%) from other sectors at the study hospital, followed by the community (43.2\%), while the remainder, coming from the Emergency Care and other hospitals, represented $8.3 \%$ of cases.

Regarding clinical severity, 899 (39.1\%) patients were classified as A, 260 (11.3\%) B, 697 (30.3\%) C, 337 (14.7\%) D and 107 (4.7\%) E. Patients were basically admitted in the postoperative period, adding up to 1,642 (71.4\%) cases. Besides, 437 (19.0\%) were admitted to the ICU diagnosed with community-acquired infection.

As for colonization by resistant microorganisms, this condition was identified in 284 (12.3\%) patients during ICU hospitalization, $61.2 \%$ of whom developed some kind of infection.

About the use of invasive procedures (central venous catheter, mechanical ventilation and indwelling urinary catheter), 1,749 (76.0\%) patients presented this characteristic. And, with regard to the diagnosis of healthcare-associated infection (HAI), this was identified in $311(13.5 \%)$ patients during their ICU stay. In 84 (27\%), resistant microorganisms caused these infections.

Outcomes included 244 (10.6\%) deaths, 97 (31.2\%) among patients who developed HAI, 64 (28.2\%) among patients with HAI caused by sensitive microorganisms and 33 (39.3\%) among patients who developed infections caused by resistant microorganisms. 
Patient distribution according to the occurrence of HAl

Table 1 - Patient distribution according to study characteristics and HAI development status. Belo Horizonte, 2009

\begin{tabular}{|c|c|c|c|}
\hline \multirow{2}{*}{ Variable } & \multirow{2}{*}{$\begin{array}{c}\text { No Infection } \\
(\%)\end{array}$} & \multicolumn{2}{|c|}{ Infection } \\
\hline & & $\mathrm{MR}^{1}(\%)$ & MS $^{2}(\%)$ \\
\hline \multicolumn{4}{|l|}{ Gender } \\
\hline Female & 46.9 & 51.2 & 50,2 \\
\hline Male & 53.1 & 48.8 & 49,8 \\
\hline \multicolumn{4}{|l|}{ Age (in years) } \\
\hline $11-56$ & 54.9 & 50.0 & 52,4 \\
\hline$\geq 57$ & 45.1 & 50.0 & 47,6 \\
\hline \multicolumn{4}{|l|}{ Origin } \\
\hline Community & 45.2 & 26.2 & 31,7 \\
\hline Other Hospital Sectors & 47.2 & 63.1 & 54,6 \\
\hline Emergency Care & 6.5 & 9.5 & 12,3 \\
\hline Other Hospitals & 1.1 & 1.2 & 1,3 \\
\hline \multicolumn{4}{|l|}{ ICU Stay (in days) } \\
\hline $1-3$ & 67.5 & 6.0 & 11,0 \\
\hline$\geq 4$ & 32.5 & 94.0 & 89,0 \\
\hline \multicolumn{4}{|l|}{ Patient Type } \\
\hline Clinical & 28.9 & 29.8 & 25,6 \\
\hline Surgical & 71.1 & 70.2 & 74,4 \\
\hline \multicolumn{4}{|l|}{ Clinical Severity } \\
\hline A & 43.6 & 9.5 & 10,6 \\
\hline B & 12.9 & 0.0 & 1,8 \\
\hline C & 29.4 & 23.8 & 41,0 \\
\hline D & 10.7 & 50.0 & 36,6 \\
\hline E & 3.5 & 16.7 & 10,1 \\
\hline Community-Acquired Infections & 16.8 & 42.9 & 29.5 \\
\hline Invasive Procedures & 72.7 & 100.0 & 96.5 \\
\hline Central Venous Catheter & 43.5 & 82.1 & 79.7 \\
\hline Indwelling Urinary Catheter & 66.3 & 96.4 & 93.4 \\
\hline Mechanical Ventilation & 45.6 & 91.7 & 86.8 \\
\hline Colonization by $\mathrm{MR}^{1}$ & 5.4 & 91.7 & 43.6 \\
\hline
\end{tabular}

$M R^{1}=$ multi-resistant; $M^{2}=$ multi-sensitive.

Resistant microorganisms as causal agents of microorganisms are described in relation to the variables infection selected after they had demonstrated statistical In Table 2, infections caused by resistant significance in bivariate analysis.

Table 2 - Estimated Odds Ratios (OR) based on logistic regression analysis, assessing the association between infection by resistant microorganism and different patient characteristics at the Intensive Care Unit. Belo Horizonte, 2009

\begin{tabular}{|c|c|c|c|c|}
\hline \multirow{3}{*}{ Characteristic } & \multirow{3}{*}{$\begin{array}{c}\text { Bivariate Analysis } \\
\text { OR* }^{*}\end{array}$} & \multicolumn{3}{|c|}{ Multivariate Analysis } \\
\hline & & & \multicolumn{2}{|c|}{ Confidence Interval 95\% } \\
\hline & & & Lower Limit & Upper Limit \\
\hline \multicolumn{5}{|l|}{ Origin } \\
\hline Community & 1.00 & 1.00 & & \\
\hline Other Hospital Sectors & $2.309^{\dagger}$ & 1.211 & 0.551 & 2.224 \\
\hline Emergency Care & $2.537^{\ddagger}$ & 1.990 & 0.455 & 5.281 \\
\hline Other Hospitals & 1.948 & 0.743 & 0.035 & 5.861 \\
\hline
\end{tabular}


Table 2 - (continuation)

\begin{tabular}{|c|c|c|c|c|}
\hline \multirow{3}{*}{ Characteristic } & \multirow{3}{*}{$\begin{array}{c}\text { Bivariate Analysis } \\
\text { OR* }^{*}\end{array}$} & \multicolumn{3}{|c|}{ Multivariate Analysis } \\
\hline & & \multirow{2}{*}{$\mathrm{OR}^{*}$} & \multicolumn{2}{|c|}{ Confidence Interval 95\% } \\
\hline & & & Lower Limit & Upper Limit \\
\hline \multicolumn{5}{|l|}{ Stay (in days) } \\
\hline $1-3$ & 1.00 & 1.00 & & \\
\hline$\geq 4$ & $32.772^{\dagger}$ & $6.359^{\dagger}$ & 1.829 & 20.006 \\
\hline \multicolumn{5}{|l|}{ Clinical severity } \\
\hline A & 1.00 & 1.00 & & \\
\hline B & 0.000 & 0.000 & 0.000 & 0.130 \\
\hline C & $3.711^{\dagger}$ & 0.582 & 0.159 & 1.552 \\
\hline $\mathrm{D}$ & $21.471^{\dagger}$ & 1.545 & 0.382 & 3.706 \\
\hline$E$ & $21.675^{\dagger}$ & 3.193 & 0.640 & 8.292 \\
\hline \multicolumn{5}{|l|}{ Community-Acquired Infection } \\
\hline No & 1.00 & 1.00 & & \\
\hline Yes & $3.716^{\dagger}$ & 0.420 & 0.239 & 1.320 \\
\hline \multicolumn{5}{|l|}{ Central Venous Catheter } \\
\hline No & 1.00 & 1.00 & & \\
\hline Yes & $5.543^{\dagger}$ & 0.658 & 0.289 & 1.582 \\
\hline \multicolumn{5}{|l|}{ Indwelling Urinary Catheter } \\
\hline No & 1.00 & 1.00 & & \\
\hline Yes & $13.746^{\dagger}$ & $7.015^{\dagger}$ & 1.653 & 26.218 \\
\hline \multicolumn{5}{|l|}{ Mechanical Ventilation } \\
\hline No & 1.00 & 1.00 & & \\
\hline Yes & $13.149^{\dagger}$ & 1.095 & 0.385 & 3.129 \\
\hline \multicolumn{5}{|l|}{ Colonization by $\mathrm{MR}^{\S}$} \\
\hline No & 1.00 & 1.00 & & \\
\hline Yes & $191.583^{\dagger}$ & $107.406^{\dagger}$ & 33.795 & 196.852 \\
\hline
\end{tabular}

* OR= Odds Ratio; $\dagger=p<0.05 ; \neq=p<0.01 ;{ }^{\S} \mathrm{MR}=$ multi-resistant.

In this study, four variables were considered to describe patients' use of invasive procedures: one is "invasive procedures", with the dichotomous response "yes" and "no", to describe the use of mechanical ventilation, indwelling urinary catheter and/or central venous catheter; the others are "mechanical ventilation", "indwelling urinary catheter" and "central venous catheter". Each of these is also dichotomous.

Due to the fact that almost $100 \%$ of patients with infections used invasive procedures, the statistical analysis models assessed this variable as a constant. Hence, these procedures were automatically removed from the analysis, as they exerted no significant effect on the response variable. Hence, for statistical analysis purposes, "mechanical ventilation", "indwelling urinary catheter" and "central venous catheter" were considered individually.

When comparing the effects of infections developed by resistant and sensitive microorganisms, in bivariate analysis, statistical significance was verified for patients diagnosed with community-acquired infections $(p=0.03$; $\mathrm{OR}=1.79$ ) and colonization by resistant microorganisms $(p<0.01 ; O R=14.22)$ upon admission. After multivariate logistic regression, clinical severity $C(p=0.03 ; O R=0.25)$ and colonization by resistant microorganisms $(p<0.01$;
$\mathrm{OR}=21.73$ ) showed to be statistically significant.

In view of this analysis, it is evidenced that, when analyzed independently from other variables, having community-acquired infections was a risk factor for the development of HAI, independently of the resistance/ sensitivity profile of its causal agent. Regarding clinical severity, this variable was statistically significant in multivariate analysis only when patients with infections caused by resistant microorganisms were compared with HAI patients caused by Sensitive Microorganisms (SM).

Assuming that colonization was significant in the presented comparisons between HAI by resistant microorganisms and SM, the fact that determined the development of infections by resistant microorganisms was colonization by these microorganisms. The identified odds ratio, considerably higher than that of other variables in bi and multivariate analysis, reinforces this idea, evidencing its greater role in infection development caused by these microorganisms.

\section{Mortality-associated factors}

Table 3 shows the bi and multivariate analysis for the possible risk factors related to deaths at the intensive care unit. 
Table 3 - Estimated Odds Ratios (OR) based on logistic regression analysis, assessing the association between mortality and different patient characteristics at the Intensive Care Unit. Belo Horizonte, 2009

\begin{tabular}{|c|c|c|c|c|}
\hline \multirow{3}{*}{ Characteristics } & \multirow{3}{*}{$\begin{array}{c}\text { Bivariate Analysis } \\
\text { OR }^{*}\end{array}$} & \multicolumn{3}{|c|}{ Multivariate Analysis } \\
\hline & & \multirow{2}{*}{$\mathrm{OR}^{*}$} & \multicolumn{2}{|c|}{ Confidence Interval $95 \%$} \\
\hline & & & Upper Limit & Lower Limit \\
\hline \multicolumn{5}{|l|}{ Origin } \\
\hline Community & 1.00 & 1.00 & & \\
\hline Other Hospital Sectors & $2.393^{+}$ & $1.434^{\ddagger}$ & 1.010 & 2.115 \\
\hline Emergency Care & $2.731^{\dagger}$ & 1.430 & 0.758 & 2.684 \\
\hline Other Hospitals & $5.948^{\dagger}$ & 1.830 & 0.547 & 6.111 \\
\hline \multicolumn{5}{|l|}{ ICU§ stay (in days) } \\
\hline $1-3$ & 1.00 & 1.00 & & \\
\hline$\geq 4$ & $5.408^{\dagger}$ & 0.846 & 0.547 & 1.299 \\
\hline \multicolumn{5}{|l|}{ Patient Type } \\
\hline Clinical & 1.00 & 1.00 & & \\
\hline Surgical & $0.547^{\dagger}$ & $0.514^{\dagger}$ & 0.351 & 0.773 \\
\hline \multicolumn{5}{|l|}{ Clinical Severity } \\
\hline A & 1.00 & 1.00 & & \\
\hline B & 2.184 & $4.216^{\ddagger}$ & 0.983 & 11.268 \\
\hline C & $10.874^{\dagger}$ & $6.977^{\dagger}$ & 3.168 & 15.300 \\
\hline $\mathrm{D}$ & $46.328^{\dagger}$ & $18.577^{\dagger}$ & 8.308 & 41.797 \\
\hline E & $210.709^{\dagger}$ & $76.490^{\dagger}$ & 32.754 & 181.836 \\
\hline \multicolumn{5}{|l|}{ Community-Acquired Infection } \\
\hline No & 1.00 & 1.00 & & \\
\hline Yes & $3.844^{\dagger}$ & 1.109 & 0.766 & 1.638 \\
\hline \multicolumn{5}{|l|}{ Invasive Procedures } \\
\hline No & 1.00 & 1.00 & & \\
\hline Yes & $17.284^{\dagger}$ & 2.743 & 0.773 & 9.470 \\
\hline \multicolumn{5}{|l|}{ Central Venous Catheter } \\
\hline No & 1.00 & 1.00 & & \\
\hline Yes & $3.287^{\dagger}$ & 0.788 & 0.532 & 1.202 \\
\hline \multicolumn{5}{|l|}{ Indwelling Urinary Catheter } \\
\hline No & 1.00 & 1.00 & & \\
\hline Yes & $5.111^{\dagger}$ & 1.467 & 1.063 & 3.467 \\
\hline \multicolumn{5}{|l|}{ Mechanical Ventilation } \\
\hline No & 1.00 & 1.00 & & \\
\hline Yes & $13.653^{\dagger}$ & $3.982^{\dagger}$ & 2.714 & 8.862 \\
\hline \multicolumn{5}{|l|}{ Colonization by MR* } \\
\hline No & 1.00 & 1.00 & & \\
\hline Yes & $6.455^{\dagger}$ & 1.472 & 0.953 & 2.277 \\
\hline \multicolumn{5}{|l|}{ Hospital Infection } \\
\hline No hospital infection & 1.00 & 1.00 & & \\
\hline $\mathrm{HI}^{\dagger+}$ by $\mathrm{MR}^{*+}$ & $8.108^{\dagger}$ & 1.501 & 0.786 & 2.811 \\
\hline $\mathrm{HI}$ by $\mathrm{SM}^{\ddagger}$ & $4.920^{\dagger}$ & 1.522 & 0.981 & 2.323 \\
\hline
\end{tabular}

Obs.: * OR= Odds Ratio; $+\mathrm{p}<0.01 ; \neq \mathrm{p}<0.05 ; \S \mathrm{ICU}=$ Intensive Care Unit; $* *$ MR = multi-resistant; †† HI = Hospital Infection; $\neq \neq$ SM= Sensitive Microorganisms

\section{Discussion}

In this study, it was verified that patients who developed healthcare-associated infections due to resistant microorganisms displayed specific characteristics in terms of time of stay at the unit, presence of community-acquired infections, accomplishment of invasive procedures and colonization by resistant microorganisms.

Studies demonstrate that ICU patients are at greater risk of developing some kind of infection. HAI caused by resistant microorganisms affect a group of patients generally submitted to greater hospital exposure, with long previous ICU hospitalizations, as verified in this 
study, where a large part of patients were admitted from other hospital sectors (other units and emergency care) and were hospitalized at the ICU for more than four days(14-15).

Besides, the severity of ICU patients makes them more vulnerable to HAI when compared with other units, with five to ten times higher probabilities of catching this kind of infection(16).

Many factors are related with the risk of catching HAI, such as disease severity, underlying disease, duration of ICU hospitalization and invasive procedures, the latter of which is frequently associated with infection by resistant microorganisms, together with high patient density and this population's susceptibility ${ }^{(10,16)}$.

In line with this finding, this research also related the occurrence of HAI with the use of invasive procedures. Among these, the use of indwelling urinary catheters stood out, which is also considered a risk factor for HAI development ${ }^{(17-18)}$.

Studies appoint that community-acquired infections affect between 13.5 and $61.3 \%$ of hospitalized patients. When caused by Methicillin-resistant Staphylococcus aureus, infection rates increase, including surgical site infection, pneumonias associated with mechanical ventilation and bacteremia(15,19-20). These studies, however, do not directly relate the presence of previous community-acquired infections with the occurrence of infections caused by resistant microorganisms.

Hence, available literature on ICU patients and infections caused by resistant microorganisms does not offer a defined profile yet that permits comparisons with the data found in this study.

Besides, patients with community-acquired bloodstream infections display mortality rates of approximately $40 \%$, against $18 \%$ for patients without reports of community-acquired infections ${ }^{(21)}$.

Patients initially colonized by resistant microorganisms developed infections in $11.1 \%$ and $4 \%$ of cases, when the causal microorganism was MRSA and VRE, respectively(22-23). In the present study, $61.2 \%$ of colonized patients developed some kind of infection, but the type of microorganism was not specified.

A consensus exists in literature that bacterial resistance has been an important factor for increased mortality rates, mainly in critically ill patients(24-25).

In the assessment of risk factors for ICU mortality, this study identified statistical significance in bivariate analysis for all study variables, except patients' gender and age. In line with this finding, other studies described $(4,10,22)$ lack of significance between gender/age and the development of infections by resistant microorganisms, even mentioning analysis of patients over 75 years of age.

Besides, some studies confirm these findings regarding the significant association between patients who developed infections and/or were submitted to mechanical ventilation, including the occurrence of deaths ${ }^{(4,10,26-29)}$. One of these studies mentions that the chance of death is between two and ten times higher for patients using this device, with death rates that can range between 24 e $76 \%{ }^{(27)}$. According to some of these studies, in patients who received mechanical ventilation, respiratory tract infection with resistant microorganisms is common and associated with higher mortality(28-29).

In literature, however, divergence exists on the association between mortality and infection development, even when using multivariate logistic regression(4,10,22). On the other hand, infections constitute independent risk factor for mortality and, to the extent that bacterial resistance to antibiotics increases, the possibility of adequate infection treatment decreases, favoring outcomes like death(26).

\section{Conclusion}

The emergence of resistant microorganisms is a source of concern for researchers and professionals responsible for healthcare-associated infection, and a priority all over the world. To establish control of these pathogens, getting to know the risk factors for infection development becomes essential, mainly when considering a clientele of critically ill patients.

ICU hospitalizations for more than four days, diagnoses of community-acquired infections upon admission to the unit, use of indwelling urinary catheter and colonization by resistant microorganisms appeared as risk factors for the development of infections by resistant microorganisms. The patients' surgical profile and clinical severity upon admission to the ICU, besides the use of mechanical ventilation, appeared as risk factors for death.

The detection of risk factors and the possibility of acting on them can enhance the control of bacterial resistance dissemination, entailing greater control of colonization and, consequently, of high infection rates at the ICU. Thus, monitoring patients with communityacquired infections and/or patients colonized by resistant microorganisms is extremely valuable for the early establishment of measures to reduce the possible dissemination of resistant microorganisms. Besides, patients with risk factors deserve special attention during care delivery by the entire health team. 


\section{References}

1. Allen S. Prevention and control of infection in the ICU. Curr Anaesth Crit Care. 2005;16 (4):191-9.

2. Graf BM, Martin E. The intensive care physician and control of antimicrobial resistante. Int J Antimicrobiol Agents. 2000;16(4):511-4.

3. Hernández G, Rico P, Díaz E, Rello J. Nosocomial lung infections in intensive care units. Microbes Infect. 2004;6(11):1004-14.

4. Peres-Bota D, Rodriguez H, Dimopoulos G, DaRos A, Mélot C, Struelens $\mathrm{MJ}$, et al. Are infections due to resistant pathogens associated with worse outcome in critically ill patients? J Infect. 2003;47(4):307-16.

5. Dhillon R, Clark J. Infection in the intensive care unit (ICU). Curr Anaesth Crit Care. 2009;20(4):175-82.

6. Lisboa T, Faria M, Hoher JA, Borges LAA, Gómez J, Schifelbain $L$ et. al. Prevalência de infecção nosocomial em unidades de terapia intensiva no Rio Grande do Sul. Rev Bras Ter Intens. 2007; 19(4):414-20.

7. Moura MEB, Campelo SMA, Brito FCP, Batista OMA, Araújo TME, Oliveira ADS. Infecção hospitalar: estudo de prevalência em um hospital público de ensino. Rev Bras Enferm. 2007; 60(4):416-21.

8. Lima ME, Andrade D, Haas VJ. Avaliação prospectiva da ocorrência de infecção em pacientes críticos de Unidade de Terapia Intensiva. Rev Bras Ter Intens. 2007; 19(3):342-7.

9. Andrade D, Leopoldo VC, Haas VJ. Ocorrência de bactérias multirresistentes em um Centro de Terapia Intensiva de Hospital Brasileiro de Emergências. Rev Bras Ter Intens. 2006; 18(1):27-33.

10. Colpan A, Akinsi E, Erbay A, Balaban N, Bodur H. Evaluation of risk factors for mortality in intensive care units: A prospective study from a referral hospital in Turkey. Am J Infect Control. $2005 ; 33(1): 42-7$.

11. Weber IC, Noal CB, Neto CHDPW, Santos RCV. Prevalência e perfil de resistência de microorganismos isolados de uma Unidade de Tratamento Intensivo de um hospital da região central do Rio Grande do Sul. Prática Hospitalar. 2009;66(6):57-62.

12. Ministério da Saúde (BR). Agência Nacional de Vigilância Sanitária. I Seminário Nacional da Rede de Monitoramento e Controle da Resistência Microbiana em Serviços de Saúde [Internet]. Brasil, ANVISA; 2009. [acesso: 08 set 2009]. Disponível em: http://www.anvisa.gov.br/servicosaude/ controle/rede_rm/1_seminario.pdf.

13. Ministério da Saúde (BR). Agência Nacional de Vigilância Sanitária. Interpretação de dados microbiológicos [Internet]. Brasil, ANVISA; 2009. [acesso: 08 set 2009]. Disponível em: http://www.anvisa.gov.br/servicosaude/controle/rede_rm/ cursos/atm_racional/modulo2/laboratorio2.htm
14. Beyersmann J, Gastmeier P, Grundmann H, Bärwolff S, Geffers $C$, Behnke M, et al. Transmission-associated nosocomial infections: prolongations of intensive care unit stay and risk factor analysis using multistate models. Am J Infect Control. 2008;36(2): 98-103.

15. Balkhy HH, Cunningham G, Chew FK, et al. Hospital- and community-acquired infections: a point prevalence and risk factors survey in a tertiary care center in Saudi Arabia. Int J Infect Dis. 2006;10(4):326-33.

16. Markogiannakis $H$, Pachylaki N, Samara $E$, Kalderi M, Minettou $M$, Toutouza $M$, et al. Infections in a surgical intensive care unit of a university hospital in Greece. Int J Infect Agents. 2009;13(2):145-53.

17. Tenke P, Jackel M, Nagy E. Prevention and Treatment of Catheter-Associated Infections: Myth or Reality? EAU Update Series. $2004 ; 2(3): 106-15$.

18. Tambyah PA. Catheter-associate urinary tract infections: diagnosis and prophylaxis. Int Jf Antimicrobial Agents. 2004;24:44-8.

19. Skov RL, Jensen KS. Community-associated meticillinresistant Staphylococcus aureus as a cause of hospital-acquired infections. J Hosp Infect. 2009; 73:364-70.

20. Ylipalosaari P, Ala-Kokko TI, Laurila J, Ohtonen P, Syrjälä $H$. Community- and hospital-acquired infections necessitating ICU admission: Spectrum, co-morbidities and outcome. Journal of Infection. 2006; 53(2): 85-92.

21. Vallés J, Ferrer R. Bloodstream Infection in the ICU. Infect Dis Clin North Am. 2009; 23(3):557-69.

22. Coello R, Glynn-f- JR, Gaspar C, et al. Risk factors for developing clinical infection with methicillin-resistant Staphylococcus aureus (MRSA) amongst hospital patients initially only colonized with MRSA. J Hosp Infect. 1997;37:39-46.

23. Olivier CA, Blake RK, Steed LL. Risk of vancomycin resistant Enterococcus bloodstream infection among colonized individuals. Infect Control Hosp Epidemiol. 2008;29:404-9.

24. Trouillet JL, Chastre J, Vuagnat A, Joly-Guillou ML, Combaux $D$, Dombret MC, et al. Ventilatorassociated pneumonia caused by potentially drugresistant bacteria. Am J Respir Crit Care Med. 1998; 157:531-9.

25. Chastre J, Fagon JY. Ventilator-associated pneumonia. State of The Art. Am J Respir Crit Care Med. 2002;165:867-903.

26. Cevik MA, Yilmaz GR, Erdinc FS, Ucler S, Tulek NE. Relationship between nosocomial infection and mortality in a neurology intensive care unit in Turkey. J Hosp Infect. 2005;59(4):324-30.

27. Cavalcanti M, Valencia M, Torres A. Respiratory nosocomial infections in the medical intensive care unit. Microbes Infect. 2005; 7(2):292-301.

28. Chien JY, Hsueh PR, Yu CJ, Yang PC. The evolution of drugresistant microorganisms in patients with prolonged mechanical ventilation. Am J Infect Control. 2009; 37(3):231-6.

29. Pappalardo F, Franco A, Landoni G, Cardano P, Zangrillo A, Alfieri O. Long-term outcome and quality of life of patients requiring prolonged mechanical ventilation after cardiac surgery. Eur J Cardio-Thoracic Surg. 2004;25(4):548-52.

Received: Apr. $15^{\text {th }} 2010$

Accepted: Oct. $21^{\text {st }} 2010$ 